\title{
Tales of the Horrors of War: Analysing Select Indian Fictions on World War I
}

\author{
Md Shahnawaz \\ Independent Scholar.Email:mdshahnawaz.ms69@gmail.com
}

\begin{abstract}
Conscription of Indian men from different states and ethnicities were recruited to fight in the First World War for the British in foreign lands, while Indian resources kept the Allies going. The discursive reduction of it quantified India to merely numbers, of soldiers given, soldiers lost, tons of food sent, and money spent. The Indian Movement for Independence as an act of political negotiation with the British masters had warranted the cultural amnesia of the Indian intellectual class about the War's impact to focus on the more vital demand, and how easily were all the unwanted marks of the War hidden and left behind. Thus, my paper will examine the representation of War in India and identify the ways in which Indian involvements in the War remain unacknowledged in the contemporary period through select works of fiction and non-fiction by Indian authors. Therefore, it is a pressing concern that much of the information about the World War I from an Indian perspective is lost, or is on the verge of being lost forever, because of the general apathy towards the preservation of such materials. This engagement with the First World War is not acknowledged the way it should be, since most of these works are not even categorized or identified as 'war literature' even if their sole concern remained precisely that. It is also important in this regard to understand the inclusion of the World War I in the silences and the omissions. Therefore, I will analyse select literary texts by Indian authors to evaluate the intersections of fiction and history alongside the enunciation of the unknown/forgotten voices of the marginalized people in the World War I.
\end{abstract}

Keywords: World War I, Indian literature, history, cultural consciousness, nationalism.

\section{Onset of The Great War}

Between August 1914 and December 1919, the British Imperial Government recruited a total of 1,440,437 (877,068 combatants and 563,369 non-combatants) Indian men for war, of whom over 74,0oo never made it back home. Wilfred Owen's anti-war poem, "Dulce et Decorum est, Pro patria mori', literally meaning 'how sweet and beautiful it is to die for one's country' is the perfect evocation for the Indian and other colonized recruits who were utterly ignorant regarding the concepts of nationalism, patriotism, and sacrifice which remained mere words repeatedly used by distant political leaders. Ultimately, 1.4 million Indians were dispatched to distant warfronts including Ypres, Festubert, Neuve Chapelle, Loos, Mesopotamia, Palestine, and others. Along with the supply of men, the Indian Munition Board was in charge of supplying food, raw materials, and textiles. People in the homeland were subjected to frequent bouts of mass starvation due to the deflection of food crops to the warfronts by the British officials. Thus, resources were being drained from across the country and heavy taxes were levied. However, these soldiers were effaced from the entire grand narrative despite India's loss of thousands of youth, resulting in fragmented families, widespread famine, and a constant atmosphere of terror and uncertainty. Despite such an enormous scale of sacrifice, no considerable attempt has been made to memorialize their contribution by English or Indian writers. My paper would aim to analyse literature in English and Bhasha languages to understand the lack of representation of Indians in the Great War and its influence on Indian Writing. Fictional works provide an

(C) AesthetixMS 2021. This Open Access article is published under a Creative Commons Attribution Non-Commercial 4.o International License (http://creativecommons.org/licenses/by-nc/4.o/), which permits non-commercial re-use, distribution, and reproduction in any medium, provided the original work is properly cited. For citation use the DOI. For commercial re-use, please contact editor@rupkatha.com. 
alternate and crucial perspective on notable historical events that help us plug in the gaps that emerge out of the perverse narrativisation that takes place subsequently. Yet, the representation of history through the lens of literature is not sufficient. It is very interesting to note that the characters depicted in fiction are fighting the war in a distant land with no direct link with their homeland. Their conversations, activities, and emotions revolve around their ongoing circumstances on the battlefield, while the only connection with the homeland is through a sense of nostalgia and remembrance. Thus, fiction has a tendency of creating a schism between these soldiers on the battlefronts and the naïve young men they were in their native land before being recruited by the imperial government. In all the novels, poetry, and descriptions written during or after the war, there is no coherent thought process or ideology followed by the writers, rather, each writer has their own point of view and opinion regarding the war. Though the fictional perspective is able criticise the conventional narration of history, it is not sufficient to justify the lived reality of the war. Through this paper, I hope to open a discussion on the complexities and problematics of Indian literature on World War I (henceforth WWI).

When Britain declared war on 4th August 1914, Lord Charles Hardinge, the then Viceroy of India, declared that India will also be partaking in their war, without even consulting the Indian leaders, but the news of the outbreak of war was welcomed by the Indian leaders and a widespread proclamation of loyalty was pledged. On 29th April 1918, Mahatma Gandhi wrote to Lord Hardinge that "[i]f I could make my countrymen retrace their steps, I would make them withdraw all the Congress resolutions, and not whisper "Home Rule" or "Responsible Government" during the pendency of the war. I would make India offer all her able-bodied sons as a sacrifice to the Empire at its critical moment; I know that India by this very act would become the most favoured partner in the Empire and racial distinctions would become a thing of the past... I write this because I love the English Nation, and I wish to evoke in every Indian the loyalty of the Englishman." However, towards the end of the WWI, the emotions and intentions took a sharp turn.

The war became a grand narrative and its memory is preserved in the form of museums, letters, memoirs, and photographs across the globe. In India, however, it received no significant mention. The socio-political upheavals surrounding the freedom movement, Independence, and Partition of India became the central narrative, pushing all other incidents to the periphery. Thus, when we seek to analyse the history of the First World War, we are actually subscribing to a history where British authorial History and its analyses of WWI is considered ultimate, whereas, the history of India's contribution receives no mention. There has been a great sense of ambiguity regarding India's contribution to the British War during the time of rising nationalist consciousness.

Along with the imperial British Army, The Great War saw the active involvement of over 500 thousand Africans and over 1.45 million Indian soldiers. This was a war of which the colonial population understood nothing and had no personal allegiance, since, they were fighting against an enemy who was unknown to them. It was done on the assumption that the British navy would fight against the German fleet in the North Sea while the armies of the continental allies defeated Germany on land. The Indian recruits felt that all would be over in a few months, if not a few weeks, and the ordinary citizen would be little affected. The temperament of the age which had recorded tremendous industrial, scientific, and cultural progress in the nineteenth century was echoed in the words of Sir Edward Grey, the secretary of State and Foreign Affairs, on 3rd August 1914 in the House of Commons: "if we are engaged in war, we shall suffer, but little more than we shall suffer, if we stand outside." It was unimaginable for the British leaders that the war could extend itself to incredible levels of suffering and agony. "Thus the duty of the civilian was to carry on normally", as Alan John Percivale Taylor, a 2oth-century British historian, was heard stating and in Churchill's words, "[b]usiness as usual". Soldiers had gone to the battlefield with great enthusiasm and a notion of honour, courage, and heroism that was 
indoctrinated in them by the imperial government. There was much idealism, a sense of jingoism, and sacrifice with little understanding of the horrors of the battlefield and hypocrisy on the part of the imperialists. This sort of misplaced patriotism had reached a point of fanaticism among the youth that had been propagandized, and the older generation which had already been conditioned to uphold the cause as pivotal to attain 'Swaraj'. Paul Fussel was an American historian-author who served in the American infantry during the Second World War and was gravely injured, has written extensively on the experiences of trench warfare. His records from the 'Times', 9th August 1914, mentions that, "[a]t an inquest on the body of Arthur Sidney Evelyn Annesley, aged 49, formerly a Captain in the Rifle Brigade, who committed suicide by flinging himself under a heavy van at Pimlico, the Coroner stated that worry caused by the feeling that he was not going to be accepted for service led him to take his life."

Finally, when the war did break out, it perpetrated more horrors than had been imagined thus far. These influenced people soon became disillusioned because of the unjust and heavy price paid by men who endured WWI by being on the forefront, since, the initial battles against the German troops were won by putting the Indian soldiers on the line. As soon as the war was over, the labour market witnessed inflation of hundreds of thousands of workers who were physically and psychologically wounded and began looking for means of a basic livelihood. Unfortunately, they lacked any kind of skill, since, they were engaged in warfare from a young age and received no opportunity to pick up any sort of vocation. It was against this background of social change that the wartime soldier having exhausted himself at the warfront returned to a life of unemployment, penury, and psychological trauma at home, which led to beholding a shift of tradition in the literature that was being produced. It becomes very important for us, as readers, to decide which episteme of history we choose to believe in. This in no way means that the nationalist narrative of freedom struggle is not true or the facts are flawed but what this paper wants to argue is that one can never generalize the experiences of all the people into a linear narrative to depict the history and append it to the idea of nation-building. So when Gandhi claimed that India as a nation was standing with the Imperial forces in their cause, he was only representing one India out of the many 'Indias'. There are as many narratives of India as there are Indians. Many photographs appeared in the British Press of the Indian sepoys who were in action on the Western Front. Interestingly, a very different and more popular set of photographs were being published throughout India of the wounded sepoys who were being taken care of by the Empire and were being nourished back to health in various hospitals along the south coast of England. Adjectives including 'tenderness', 'foster', and 'virtuous' were attributed to these hospital photographs as imperial England sought to showcase themselves as the philanthropic paternal figure.

\subsection{Revisiting Literary and Archival Records of Soldiers}

By 31st December 1914, the Indian Corps had suffered 9,579 casualties in addition to 1,397 deaths. By the end of 1915, the number had risen to 28,80o. 'The Brighton Herald' on 14th December 1914 had the headlines 'Arrival of Indian Wounded' in a bold, big font and throughout 1915, the press continued to describe Indians with adjectives such as 'magnificent men', 'brown warriors', 'Eastern Warriors', and 'our guests from beyond the seas'. It is against this backdrop that Rudyard Kipling writes his The Eyes of Asia, published in 1918. Through his text, he wanted to give the ordinary sepoy a voice and he does so by writing four short stories in the form of letters. The first three epistolary stories, "A Retired Gentleman", "The Fumes of the Heart", and "A Trooper of Horse", take the form of letters where Kipling imagines himself to be a wounded Rajput, a Sikh, and a Muslim sepoy, respectively, writing from English hospitals. "The Private Account", on the other hand, recreates the scene of reading of one such letter by the family of the sepoy back in India. What is note-worthy here is that in each of his letters, Kipling represents his sepoy as an uneducated figure overwhelmed by the superiority, generosity, and righteousness of the British Empire. Kipling depicts the character of Bishen Singh Saktawut in 
"A Retired Gentleman", who is a proud Rajput and was a Subedar Major in 215th Indurgurh [Todd's] Rajput regiment. He is writing a letter to his friend, Madhu Singh Sawant, who is now retired (despite being three years younger than Bishen Singh) and is enjoying his life on his fief, where he recounts his memories of the War. In his letter, he talks about the treatment he is getting at the hospital he was admitted to after getting wounded. He goes on to praise the doctors and nurses who are busy tending to the wounded. He makes it a point to state the fact that the head nurse in the hospital is a Baroness but she is not hesitant to tend to the ill and the wounded. He informs his friends that these nurses treat him as their father and they would be struck with grief if he leaves for India. The sepoy letters from the Brighton Pavilion hospital that catered to the medical and religious needs of the Indian soldiers, however, tells a very different story. There are two images that I would like to cite and explicate. First, of Subedar Major, Bishen Singh Saktawut, as portrayed by Rudyard Kipling, who after receiving the medal, The Victoria Cross, was asked by the Baroness to stay at her residence in the city. The Victoria Cross was considered the highest and most prestigious award of the British honour system bestowed on the British Armed Forces of the Commonwealth nations and was personally presented by the British monarchs, ideally in Buckingham Palace. He goes on to describe his stay in the house as a "palace filled with carpets, furniture, silks, velvets, carvings... hot water ran in silver pipes to the bedside. The perfumed baths were perpetually renewed. I inhabited here for ten days. Though I was utterly useless, they were unwearied of me" (p. 5). He goes on to make a statement that it is the nature of the English to consider all created beings as equal. These accounts unwittingly revealed the severe conditioning of the colonized people and the manipulation implemented by the imperial forces on these tortured souls as well as the larger population in the homeland by the extensive circulation of the idea of a philanthropic Britain amongst the general mass of Indians. The other image is that of Jemadar Mir Dast who was given the Victoria Cross by King George V. He claimed that the Victorian Cross might have been a fine thing but it was constipation that gave him no rest. It is the horror of the war which was being reflected through his words. The narrative of the two Indian soldiers differ vastly in tone and emotion; one, eulogizing the British masters for their imaginary display of favours, while the other, revealing the charade of the real irony.

The British feared that the Indian sepoys might get involved with English women so fences were erected around the hospital grounds to prevent any sort of intermingling. These health care centres resembled more of a correctional centre than a hospital where wires girdled the facility grounds and police guards were stationed outside the Indian units. Letters from Pirzada, a sepoy of the Imperial Army confirmed that although they are well-fed and given clean clothes, they were denied their freedom: "They [English] do not even allow us to the bazaars" (Das, 2018, p. 163). Unlike Kipling's Madhu Singh who is sent back to India after suffering wounds, there is a contrasting image that forces the sepoys back to the trenches after recovery. It was Mir Dast himself who wrote a letter to the King while he was in Brighton Pavilion stating that "the heart of Indians are broken... the Indians have given their lives for eleven rupees ... any man who comes here wounded is returned three or four times to the trenches. Only that man goes to India who has lost an arm or leg or an eye" (Das, 2018, pp. 163-164). Kipling refers to the Indian participation in the Great War as an obligation towards the Government in The Eyes of Asia. Bishen Singh Saktawut writes a letter where he instigates Madhu Singh to come out of his house and fight again since, "[t]he Brahman who steals, the widow who wears ornaments, the Rajput who avoids the battle are only fit for crow's meat" (p. 3) The protagonist-speaker defines the enemy as an "outcaste" and their nature was to bring about shame upon women and children. He goes on to compare them with apes, running on all fours to attack. Through Madhu, Kipling reveals the benefits of the education system which was brought to India by the Imperial Government. He compares the unlettered Thakore Sahib of Philawat, who refused to go to war on account of dedicating his youth to his education. Hence, his "accomplished" sister, who married the Rana of Haliana, helped him prepare a contingent of infantry out of her own 
dower villages. Madhu himself is loyal of the Imperial Government where he claims that "if the Government can be served with the dust of my bones it is theirs... Man does not remain in the world but his name remains. Though Jam and Suliman are gone their names are not lost" (p. 7). These words exemplify the British project of enlightenment and colonialism and are considered successful endeavours of the White Man's burden.

"Usne Kaha Tha" or, "She said so" by Chandradhar Sharma Guleri provides a stark contrast to the depiction of Indianness that Kipling had explicated. Considered to be one of the first short stories to evoke the experiences of the trenches from the perspective of an Indian soldier, Guleri's "Usne Kaha Tha" develops its narrative in a different direction to that of factbased Eurocentric history. The story becomes an archive of some of the deepest anxieties and ambitions confined in the sepoy's heart. The widely displayed aggressive pledge and proclamation of loyalty was widespread amongst the gullible lower-class Indians, easily manipulated with the promise of land or upward social mobility through a public investiture of honours. Lehna Singh who is the protagonist of the story asks some pertinent questions regarding the nature of the war. By making Lehna his mouthpiece, Guleri critiques the false notions regarding the thrill and pride enjoyed by the soldiers during and after the experiences on the battlefields. Most importantly, his words echo a sense of isolation and grief evident in the stifled voices of the Indians who were far away from their native country, fighting in a foreign land. Lehna Singh laments, "Ram, Ram! Do you call it war? My bones have turned stiff by sitting in these damned trenches day and night. And it is freezing cold- ten times colder than in Ludhiana... and one is knee-deep in slush all the time." These words draw a stark contrast against the rose-tinted images portrayed by the world leaders and news reports. Guleri's words seem like a precursor to Wilfred Owen's most popular poem "Dulce et Decorum Est." He goes on to describe the inhuman conditions of the trenches in a vivid and precise manner through Lehna Singh who claims that "there is no enemy in sight. Only the gun booms every hour or so splitting one's eardrums and shaking the whole trench. If one's turban or elbow is visible above the trench, a bullet comes whistling through the air, ripping through one's turban." This feeling of uncertainty along with a constant fear looming in their minds differs from the familiar scurry of everyday life in Amritsar where the story concludes. These constant contrasting images demonstrate the sudden turn of events in the lives of these young men who are thrown into this desolation and meaninglessness. Opening in a rich stirring space of Amritsar, Guleri problematizes the story by shifting the narratives to the trenches creating a glaring disparity between the two different spaces occupied by the sepoy. Guleri effectively unfolds the politics which exists within the system. In the story, the English officer goes missing and his place is taken up by Jemadar Lehna Singh. Guleri creates a situation in which a real-life Indian sepoy would never find himself. He reflects on the politics of the Imperial Army where Indian sepoys always suffered from subordination and humiliation. Believed to be belonging to the martial race, they were expected to be brave but were denied the position of leadership, management, and decision making. They were never considered to be worthy of any position of power and it was always the White Man's burden to educate and guide the colonial subjects. This short story problematizes this very issue by depicting Lehna Singh as the leader who can predict, plan, and analyse the moves of the enemy, a trait naturally present amongst the farming communities in Asian cultures, who have to remain constantly alert of the surroundings to defend and reap maximum produce. "Usne Kaha Tha" thus, becomes a fantasy regarding leadership for the sepoys who were denied these privileges in reality but realized through fiction.

\subsection{The Politics of Literary Representation}

Mulk Raj Anand writes Across the Black Waters (1940), the second part of his Lalu trilogy which starts with The Village (1939) and ends with The Sword and the Sickle (1942). Anand's novel becomes very important because until then there was only a fragmented understanding of a sepoy's consciousness. With Across the Black Waters, Anand provides a detailed description 
of a sepoy's inner world, written from the perspective of a subaltern. The narrative tries to understand the imagination, perspective, and understanding of a sepoy by delving deep into his inner realm of feelings which has been shaped by a history of race, class, war, society, and the British Empire. The narrative focuses on the fortunes of the 69th Rifles which included people of Dogra, Baluchi, Sikh, and Punjabi Mohammedan regiments, and through their characters, attempts to problematize the conventional history. These deviating points of view from these Indian soldiers belonging from various class and religious backgrounds, sharing a feeling of empathy, makes for not only an interesting but also a very significant narrative as Anand depicts a group of men who, after being away from their homeland, are united as singular identity as Indians. This gives rise to a strange irony, since, the imperial forces maintain and reinforce a clear distinction of class and caste amongst the colonized recruits to retain control over them. This divide is solemnly observed in the homeland, yet, once they are away from their native land in a foreign milieu, a sense of Indianness and brotherhood emerges amongst them. This sense of unity and fraternity becomes their solace in the desolate and inhospitable battlefields. Following the tradition of travel literature, the narrative focuses on the colonial encounters after the Indian troops arrive at Marseille. Anand tries to focus on the concept of the gaze by positing the binaries of the orient and the occident which leads to the colonial association of the master and the subordinate, the enlightened and the ignorant, and the signifier and the signified. He focuses on the 'uncivilized' and 'uncultured' Indian villagers embarking on their journey to Vilayet, meaning foreign, for the first time. "Marsels! We have reached Marsels!" the Indians shouted from the deck of their ships as they came close to witnessing their Vilayet. They wander around Orleans and visit the markets, bars, and brothels. As Lalu is blinded by the shining display of foreign objects on the shop windows, a comparison is drawn between the shops in France and the ones back in India and Uncle Kirpu is heard commenting that the shopkeepers in India do not have enough money to spend on decorations. Lalu's notion of Europe as a heavenly place comes crashing down when Uncle Kirpu reminds him of the prevalent caste system and discrimination stringently practiced in Europe, "[t]he Sahibs travel first class... The Indian Officers second class, Tommies, havildars, naiks and sepoys in the third class... remember this and don't be led astray" (p. 8o). There is no instance of overt racism but Anand focuses on the racist and colonial ideologies internalized by the Indian soldiers, "I feel afraid to enter... We might be reported" (p. 84), which is what Kirpu feared when he was about to enter a café, "[a]t that, the Frenchman bowed very politely, smiled and went his way, 'Salaam Huzoor' said the sepoys saluting and almost coming to attention in the face of a white man. For all white men, military or civil were to them superior like the English Sahibs in India who surrounded themselves with princely airs" (p. 84). This kind of mental subjugation was perhaps the biggest triumph of the British Government, far more than the political or economic dominance. Throughout the novel, Kirpu draws comparisons with the white natives and refers to himself and fellow Indians as oxen owing to the 'brownness' of their skin. There is a feeling of inferiority, a sense of distance, and fear, even when they encounter a 'memsahib' or white woman. He feels "too humble to stare at this superior life" which was displayed at the shops in the market. Lalu, thus, echoes the thoughts and voices of many other sepoys who perhaps, experienced the same emotions. These are narratives that would never be documented under the history of race and the empire. When staring at a platoon from North Africa, Kharu commented that the African soldiers were unlike them as they are black, not brown, emphasizing his racial superiority. Simultaneously, Lalu felt remorse emerging from this false of superiority and maintained a distance from them. This schism between the colonial cultures based on skin colour and appearance is one of the many colonial residues and these factions were further reinstated by the imperial government to maintain stability and superiority over the colonies. All these instances throughout the novel are part of colonial offshoots. These incidents bring out the trope of the 'western gaze', whereby, a person's social status is determined by their appearance, more specifically, by the colour of their skin. The White Man is at the top of the hierarchy, 
followed by the brown population, leaving behind the Negro, at last. Hence, the Indian soldier feels a sense of anxiety and wants to distance himself from the African soldiers as he feels superior according to the imperialistic strata of society. Through the space of a novel, Anand brings out the issues of inter-racial encounters amongst the soldiers during the war. Hence, he shows that it was not only the Empire that was under attack but the mentality of the Indians as well that has been influenced by the feudal economy and hierarchy for centuries. A significant aspect of writing fiction is the role it plays in dealing with conventional history. When we are discussing history, we must understand that we are trying to read or understand different points of view. Fiction has the power to move the audience through its effective manoeuvre of language and can stitch them together, and eventually critique the conventional history that pervades our society. Abdullah Hussein's Udaas Naslain (1963) sheds light in these regards where it tries to discuss the nature of the war and in doing so, gives us an insight into the politics of our national history under colonial rule.

The need for artistic wisdom in a time of great calamity is very important as that gives us a sense of hope and perhaps a direct call to action which Tagore did in his own poetic way. In June 1914 he tells Ramananda Chatterjee, editor of Modern Review and Probashi that he is going to leave Shahitya-khetra or the world of literature. He was very sensitive to what was going on across the globe and this was also the time when he was writing, as a professor of History at Calcutta University, Dr. Kalidas Nag's words, his "War Poems", 'Ebar bujhi elo shorboseshe'. He wrote 'Amra Choli 'on the 2oth and 26th May saw the publication of 'Sankha'. War was inevitable at that point of time and 'Sankha' became a crucial poem that was published in the 'Times' and was translated as 'The Trumpet'. Professor Ananda Lal, a dedicated theatre critic and director and an ex-professor at Jadavpur University, however, translates 'Sankha' as 'Conch'. This is the conch that summons young men to war. His 'Crossing', published in the 'Indian Ink' on 22nd August 1914, depicts the imagery of a lone boatman crossing the 'wild seas at night... poisoned with black fear.' By 1916, Tagore was very disturbed by the events of war and started writing about it, however, there is no mention of the Indian soldiers in his poems which is reflected in Swarnakumari Devi's 'Mutiny' that depicts a vivid scenario of the war. She was one of the first Bengali women to gain prominence as a writer and activist. She also served the Indian National Congress from the year 1890. All these events inspire Sarojini Naidu to write her poem 'The Gift of India' in 1915 where she commemorates the Indian soldiers and reminds the general population of the sacrifices made by them. She memorializes the benign, selfless attitude of the mothers to have sent and lost their sons to war at the appeal of the Indian leaders. The image of an Indian mother is poignantly depicted through her words and the readers can feel the empathy towards the soldiers as well as their kith and kin. It is one of the most significant anti-war poems written by an Indian woman who understands the immense loss incurred by India as she equates the youth of the nation as "jewels". These youth were India's greatest asset in its freedom struggle and were a potential future of the nation.

Invariably, most of the fictional accounts give us a feeling of distancing the real and the re-counted, the experience and the chronicled. Furthermore, while talking about the Indian contribution to the war, we have only been discussing the people who have fought in the war fronts. It is important to understand and acknowledge the role of each person. The focus of our narrative has always been people who have risked their lives. It is their representations that we get in the fictional narratives. But we must remember that the Imperial Government recruited a huge number of non-combatants including cooks, washer-men, cleaners, and people from the lower caste. What we must realize that at some level there is at least a representation of the soldiers. The class and caste differences exist between them as well but what about the people who have absolutely no mention in history. We must question the inconsistencies, discrepancies, and assumptions that have been made while writing public history. Thus, there is a requirement of a certain kind of co-existence between the real and the fiction, the public and the private, and the objective and the subjective. My paper raises this significant question 
that when we are remembering and re-analysing history through literary works, are we not circumscribing at certain points; are we really acknowledging the feats of the unsung heroes and commemorating the neglected stories that remain hidden from the public eye to this very day; or, is it a mere re-writing of history based on a particular episteme where British authorial history re-fashions and canonizes the WWI as a record of their dominant and revolutionary past. With these questions and concerns, I hope to begin identifying the problems and engage in a discourse on the politics and inadequacies in the representation of the War in the fictional writings of the time and those written later.

\section{References}

Anand, Raj Mulk. (1939). Across the Black Waters. Orient Paperbacks.

Bagchi, Amiya Kumar. (2014). Indian Economy and Society during World War One. Social Scientist, 42(7/8), 5-27. JSTOR, www.jstor.org/stable/24372918

Burton, Antoinette. (2005). Archive Stories: Facts, Fictions and the Writing of History. Duke University Press.

Burton, Antoinette, \& Kennedy, Dane (Eds.). (2016). How the Empire Shaped Us. Bloomsbury Academic.

Chopra, K. Vijay. (2006). The Great War and the Novel. Abhijeet Publications.

Das, Santanu. (2018). India, Empire, and First World War Culture: Writings, Images and Songs. Cambridge University Press.

Guleri, Chandradhar Sharma. Usne Kaha Tha (Madhavi Mahadevan, Trans.). (Original work published 1916) https://madhavimahadevan.com/usne-kaha-tha-she-had-said-it/

Hussein, Abdullah. (2016). The Weary Generations. New Delhi: Harper Perennial.

Jack, George Morton. (2018). The Indian Empire at War. Little Brown.

Jack, George Morton. (2006). The Indian Army on the Western Front, 1914-1915: A Portrait of Collaboration. War in History, 13(3), 329-362. JSTOR, www.jstor.org/stable/26061960

Jalil, Rakshanda (Ed.). (2019). The Great War: Indian Writings on the First World War. Bloomsbury India.

Kipling, Rudyard. (1918). The Eyes of Asia. Doubleday Page and Company.

Omissi, David (Ed.). (1999). Indian Voices of the Great War: Soldiers' Letters, 1914-18. Viking.

Omissi, David (Ed.). (1994). The Sepoy and the Raj: The Indian Army, 1860-1940. Macmillan Press Ltd.

Pati, Budheshwar. (1996). India and the First World War. Atlantic Publishers and Distributors.

Sampson, Anthony. (2005). Freud on the State, Violence, and War. Diacritics, 35(3), 78-91. JSTOR, www.jstor.org/stable/4621043.

Singh, Amarinder. (2014). Honour and Fidelity: India's Military Contribution to the Great War 1914-18. The Lotus Collection.

Taylor, Percivale John Alan. (1966). The First World War: an Illustrated History. Penguin Books.

Tinker, Hugh. (1968). India in the First World War and After. Journal of Contemporary History, 3(4), 89107. JSTOR, www.jstor.org/stable/259853 